\title{
Vernuwing in gemeenskapsbelewing binne die Gereformeerde Kerke in Suid-Afrika
}

\author{
J.M.Vorster \\ Dept. Dogmatologı/e/Ekklesiologie \\ Potchefstroomse Universiteit vir $\mathrm{CHO}$ \\ POTCHEFSTROOM
}

\begin{abstract}
Renewal in the experience of fellowship in the Reformed Churches in South Africa (GKSA)

Experiencing true koinonia is one of the major problems of the church today. This problem is a remnant of the modemist period in Western culture with its emphasis on rationalism. Because of the simultaneous process of urbanisation with its subculture of individualism. privatisation and alienation, modem man is not capable forming firm and lasting spiritual relatıons. The modern generation is a "me-generation" with the emphasis on the rights of the individual. This article explores the way in which Reformed ministry in South Africa can be renewed to address the quest for community in a post-moxdern environment. Attention is paid to societal factors preventing the experience of true koinonia in the contemporary church. Various proposals aimed at enhancing the true experience of koinonia are suggested - practical suggestions concerning everyday ministry and the role of the believer.
\end{abstract}

\section{Inleiding}

Gemeenskapsbelewing tussen gelowiges is 'n wesentlike deel van kerk-wees. Die gemeenskap moet nie net, soos in die Apostoliese Geloofsbelydenis, bely word nie. Hicrdie gemeenskap tussen gelowiges moet in al die aspekte van die funksıonering van die kerk gemanifesteer en weerspieël word. Vervreemding en vercensaming van gelowiges stry teen die wese van die kerk. Na hierdie aspek is reeds elders verwys waar die betekenis van Bybelse beelde van die kerk en die implikasies daarvan vir kerk-wees behandel is. Die Bybelse beelde van die kerk dui aan hoe belangrik die belewing van gemeenskap is (Vorster, 1994:509).

In hoeverre word hierdie belangrike eienskap van die kerk weerspieêl in die gereformeerde kerklike lewe van vandag? Hendriks (1992:14) sê, onder andere, dat die gevestigde hoofstroomkerke gekenmerk word deur die instituutmodel wat beteken dat alle aktiwiteite opgaan in die kerklike ampte en dat van gemeenskapsbelewing weinig teregkom. Mead (1993:18) merk dieselfde op en sê dat hierdie stand van sake toegeskryf moet word aan die feit dat die kerke nog gebuk gaan onder die invloed van 'n verbygegane paradigma waarin die kerklike 
struktuur, met 'n sterk nadruk op die funksie van die klerus, sentraal staan. In navorsing oor Gemeentebou in Suid-Afrika word van hierdie instituutmodel ook gepraat as die herder-kuddemodel omdat die gemeentelike aktiwiteite in alle belangrike sake draai om die ampswerk van die predikant. Hoewel die herderkuddemodel in sy regte vorm as een van die vele Bybelse modelle beskou kan word, mag diẻ model nie teenoor ander modelle verabsoluteer word nie. Breytenbach (1992:391) toon dit met duidelike Skrifgronde aan.

'n Duidelike aanduiding van die belangrikheid van gemeenskapsbelewing in die Bybelse siening oor die verhouding tussen gelowiges word gegee deur Louw (1990:233-234). Hy sê, met verwysing na Versteeg, dat die volk van God in die Ou Testament gekenmerk is deur "representasie", met ander woorde, dat priesters namens die volk opgetree het. In die Nuwe Testament is hierdie "representasie" volgens hom egter vervang met "partisipasie" wat beteken dat gelowiges gesamentlik in gemeenskap met mekaar voor die Here staan. Die verskil tussen Ou en Nuwe Testament moet in hierdie verband weliswaar nie te ver gevoer word nie omdat die gemeenskap in die geloof ook in die $\mathrm{Ou}$ Testament belangrik geag is. Tog is Louw korrek in sy siening dat gemeenskapsbeoefening en gemeenskapsbelewing in die Nuwe-Testamentiese kerk van kardinale belang is. Hierdie belangrikheid spreek uit die begrip koinonia en die belangrike plek wat aan die begrip in die Nuwe-Testamentiese kerkbeskouing toegeken word.

In hierdie artikel word besin oor die problematiek rondom konkrete gemeenskapsbelewing in die praktiese funksionering van die teenswoordige Gereformeerde Kerke in Suid-Afrika (GKSA). Eerstens word die Bybelse begrip koinonia behandel. Daarna word gelet op die soeke na gemeenskapsbelewing soos dit in die huidige samelewing na vore kom. Dan word die hedendaagse struikelblokke in die weg van ware gemeenskapsbeoefening aan die orde gestel en ten slotte word die fokus gestel op die konkrete wyse waarop gemeenskapsbelewing tans verwerklik kan word.

\section{Die betekenis van koinonia}

Die begrip koinonia met sy newe-begrippe word veral in die briewe van Paulus en in die briewe van Johannes aangetref. Neuenzeit (1961:368) gaan so ver om die begrip 'n grondlyn in die teologie van Paulus te noem. Ook by Johannes speel die begrip ' $n$ baie belangrike rol, veral in die beskrywing van die geloofsverhouding van die gelowige met Christus. Die grondbetekenis van die woord is "om deel te hẻ aan". Hierdie "deelhê aan" word dan in verskillende verhoudinge en fasette uitgespel (Hauck, 1968:789).

In 1 Korintièrs 1:9 beskryf die begrip die gelowige se deelgenootskap aan die weldade van Christus. Die gelowige het deel aan die geestelike gemeenskap met 
die opgestane Christus. Die deelgenootskap word ook sigbaar uitgedruk in die gelowige se deelgenootskap aan die Nagmaal (1 Kor. 10:16) wat 'n aanduiding is van sy deel-wees van Christus deur die ware geloof. Hierdie gemeenskap met Christus is 'n gemeenskap met sy sterwe en opstanding (Rom. 6:8); met sy lyde (Rom. 8.17) en 'n teken dat die gelowige saam met Christus "begrawe is en opgestaan het" (Kol. 2:12; 3:1; Ef. 2:6). Die begrip word ook deur Paulus gebruik om uitdrukking te gee aan die gelowige se deelgenootskap aan die seëninge van die evangelie ( 1 Kor. 9:23; Fil. 2:1) en aan die Gees ( 2 Kor. 13:14; Fil. 1:5).

Maar benewens die gebruik van die begrip as aanduiding van die gelowige se mistieke geloofsverhouding met Christus, word die uitdrukking ook op 'n wye vlak gebruik as beskrywing van wat die onderlinge verhouding van gelowiges, as nuwe mense in Christus, met mekaar moet wees. Seesemann (1933:87) lê baie klem op hierdie aspek in sy deeglike analise van die begrip koinonia in die Nuwe Testament. Die verhouding tussen gelowiges word met dié woord ook beskryf as 'n geestelike eenheid in die ware geloof ( 1 Joh. 1:3). By Paulus beskryf die woord die samewerking wat daar tussen gelowiges moet wees (2 Kor. 8:23) en die konkrete mededeelsaamheid wat gelowiges met mekaar behoort te beoefen (McRay, 1984:414). Skrifgedeeltes wat in hierdie opsig belangrik is, is Romeine $11: 3 ; 12: 13 ; 15: 26$; Galasiërs 6:6 en Filippense 4:15.

Koinonia wys dus op die "driehoekige verhouding" wat tussen gelowiges en Christus en gelowiges met mekaar bestaan. Hierdie verhouding dui op sowel 'n diep geestelike verhouding in gemeenskaplike geloof as liefde en op 'n sigbare konkrete verhouding waarin die gelowiges liefde aan mekaar in sigbare dade bewys. Die begrip omvat dus al die aspekte van die gelowige se gemeenskapslewe. Dit sluit ook die daaglikse taak van die gelowige en die roeping van die kerk in. Von Arx (1989:227) sê daarom tereg dat die begrip betekenısvol is vir die hele lewe van die kerk. Volgens hom moet alles in die kerk gerig wees op die belewing en die herstel van gemeenskap.

Schilder (1953:74) het in 1953 tot dieselfde konklusie gekom in sy dogmatiese beredenering van die begrip. Hy sê dat daar in die wêreld twee tipes gemeenskapsbelewing bestaan, naamlik die gemeenskap tussen alle mense en die gemeenskap tussen Christene. Eersgenoemde omskryf hy met die Griekse woord sunousia. Hierdie woord heteken "die samesyn van mense". Hierdie vorm van gemeenskap dui op 'n blote horisontale verhouding tussen alle mense kragtens hulle mens-wees. Koinonia, daarenteen, omskryf die vertikale verhouding met Christus en op grond daarvan die verhouding wat daar tussen gelowiges moet wees. Die taak van die kerk en die Christen is dan om uit die sunousia die belcwing van koinonia te skep. Hierdje taak is die diepste essensie van alle Christelike roepingsvervilling. Schilder toon met beredenering van die begrip 
koinonia aan hoe wesenlik belangrik die konsep van gemeenskap en gemeenskapsvorming in die kerk is. Die begrip omskryf dus nie net ' $n$ toestand nie, maar ook 'n doelgerigte aktiwiteit. Die gelowige moet koinonia soek en beleef. Dieselfde gedagtes word gevind by Dulles (1987:47) en Campbell (1989:12).

Samevattend kan dus in hierdie verband gesê word dat die uitdrukking koinonia 'n onmisbare eienskap van die kerk omskryf. Die begrip dui enersyds op die innige gemeenskap van die gelowiges met Christus en met mekaar en daaruit voortvloeiend die taak van die kerk om hierdie gemeenskap te bewaar, te bevestig en uit te bou. Sowel die wese as die taak van die kerk word met dié woord aan die orde gestel. Sonder ware gemeenskapsbelewing en gemeenskapsvorming is die kerk nie kerk nie. Wanneer die kerk hierdie aspekte nie meer in die algemene praktyk van kerk-wees weerspieël nie, het die tyd aangebreek vir selfondersoek en vernuwing.

\section{Die soeke na gemeenskapsbelewing}

Gemeenskapsbelewing word ook in die huidige kultuur al hoe belangriker. Die huidige kultuur word al hoe meer as 'n postmodeme kultuur beskryf. Edgar (1995:359) lê ook hierop klem in 'n onlangse behandeling van die begrip. Die postmodernisme is 'n paradigma wat homself stelselmatig in die wêreld van vandag manifesteer (Küng, 1995:775). Hierdie postmoderne paradigma bring ten opsigte van gemeenskapsbelewing ook nuwe sake onder die aandag. 'n Nuwe werklikheid met nuwe eise kom langs die verbygaande tradisionele werklikheid te staan soos Kuhn (1970:111) die proses uiteensit in sy beskrywing van paradigmaverskuiwings. Die verskuiwing bring mee dat die mens nuwe behoeftes ontwikkel wat anders is as die behoeftes van die verlede (Küng, 1991:6). Nuwe en ou behoeftes staan langs mekaar omdat twee paradigmas vir 'n tyd lank parallel bestaan.

Teenoor die bestaande en erkende probleme van die sekulêre mens ontwikkel die postmoderne mens dus ook nuwe behoeftes. Die belangrikste hiervan is 'n besondere behoefte aan die aktiewe belewing van gemeenskap. Dit, ten spyte van die bekende gees van individualisme wat vanweë die ou paradigma die hedendaagse mens steeds kenmerk. Hierdie diepgevoelde behoefte moet gesien word as die mens se reaksie op die reste van die modernisme wat nog as 'n verbygaande paradigma in die wêreld teenwoordig is.

Die modernisme, met sy beklemtoning van die rede en die rasionele benadering tot die werklikheid het die mens gedehumaniseer. Dehumanisening beteken dat die mens vanweě sy manipulasie deur die wetenskap en tegniek geestelik losgemaak is van sy omgewing en sy medemens. Hierdie tendens is in die sewentigerjare raak getipeer deur Marcuse (1971:10) met sy stelling dat die moderne mens nie leef nie, maar "geleef word" deur die wêreld van tegnologie 
en industrieè. Die mens kan nic meer sy innerlike behoeftes en talente uitleef nie. Hy is ' $n$ rat in 'n groot masjien. Hoewel hy ingeskakel is in die groot geheel, is hierdie inskakeling kunsmatig en meganies, want dit maak hom los van sy natuurlike verhoudinge.

Die kultuur van die modernisme waaraan dic wêreld vir twee eeue onderhewig was, en in 'n mate steeds is, het op hierdie wyse die vraagstuk van vereensaming geskep. Stott (1992:232) sê dat die moderne tegnokratiese samelewing die normale gemeenskap tussen mense vernietig het. Die mens leef in 'n tyd van sosiale disintegrasie waarin mense dit toenemend moeilik vind om verhoudinge met mekaar op te bou; daarom soek die postmoderne mens juis dit wat hom, as gevolg van die moderne samelewing ontwyk, naamlik liefde. Hiermee saam word gesoek na 'n spiritualiteit waarin 'n gemeenskaplike ervaring van blydskap in die Here 'n belangrike kumponent is (De Haan, 1996:15).

Die eise van die Bybel en die eise van die tyd maak dit dus vir die kerk noodsaaklik om weer te besin oor hoe die gemeenskap van die gelowiges so ingeklee kan word dat die koinomia vandag en in die tockoms aan sowel die beginsel as die praktyk kan beantwoord (Edwards, 1987:444). Wuthnow (1993:32) maak die volgende veelseggende stelling: "The church of the twentyfirst century, like that of previous centuries, will probably remain vibrant as long as it can provide people with a strong sense of community." Edgar (1995:375) gaan ten opsigte van dieselfde saak selfs so ver as om te pleit vir 'n "postkerklike teologie" waarin die klem verskuif word van die kerk as 'n struktuur na die kerk as gemeenskapsbelewing. Ook in hierdie verband word die tradisionele instituutmodel nie beskou as doeltreffend in die beantwoording van die mens se soeke na gemeenskap nie.

'n Aanduiding dat so ' $n$ verskuiwing weg van die instituutmodel reeds besig is om plaas te vind, blyk uit die groei van kleingroepe waarin gelowiges buite die verband van die geìnstitueerde kerk allerlei vorme van gemeenskap met mekaar beoefen (Gibbs, 1992:155; Burger, 1995:91). Vanuit Gereformeerde oogpunt sal aan die saak aandag gegee moet word op so 'n wyse dat die beginsels vir bediening konkreet gestalte kry in nuwe bedieningsmodelle waarin die soeke na gemeenskap betrek word (vgl. Brueggeman, 1991:128). In die proses sal nie net gekyk moet word na die beginsels wat ter sprake is nie, maar ook, en veral, na die aspekte in die milieu en funksionering van die hedendaagse gemeente wat, as gevolg van die teenswoordige paradigmaverskuiwing, egte gemeenskapsbelewing bemoeilik Hieraan word vervolgens aandag gegee 


\section{Struikelblokke vir ware koinonia}

\subsection{Westerse individualisme}

Die modemistiese paradigma, wat sedert die Verligting die Westerse denke bepaal het, het die kerk algaande gekonfronteer met 'n gees van sekularisasie (Pannenberg, 1989:1). Die kerklike omgewing het koud en afsydig geword teenoor godsdiens en spiritualiteit oor die algemeen. Die mens het homself ingestel op dit wat hy rasioneel kan ken en begryp en die Christendom gereduseer tot die vlak van 'n natuurlike godsdiens (Bromiley, 1978:343). Gepaardgaande daarmee het ' $n$ radikale humanisme opgebloei wat die mens die maatstaf van alle dinge gemaak het. Hierdie radikale humanisme was anti-kerk en anti-Christelik (Aland, 1986:269). Verskeie belangrike geesteshoudinge het hieruit voortgevloei - verskynsels soos die twintigste-eeuse pragmatisme en 'n hedonisme wat direk in stryd is met die gereformeerde godsdiensbelewing. Hierop wys Gibbs (1993:159) in sy omvattende navorsing oor die struikelblokke in die weg van moderne kerklike bediening.

Die belangrikste gevolg van die gees van sekularisasie van die modernisme is egter die lewenshouding van individualisme wat in die twintigste-eeuse kultuur posgevat het (Edgar, 1995:376). Met individualisme word bedoel dat die mens homself primêr op sy eie behoeftes instel en sy lewe op homself rig. Hierdie lewenshouding het ook die kerk binnegedring. Whutnow (1993:38) meld, na 'n ondersoek wat hy in hierdie verband gedoen het, dat die meerderheid kerkgangers beweer dat hulle eerste na hulle eie behoeftes moet omsien en dan eers na die behoeftes van ander mense. Hy noem die huidige geslag die "me-generation" en die "mine-generation". Hy sê ook dat die individualis in hierdie tyd as die heldefiguur beskou word "Critics say we have become a nation of individualists, obsessed with our jobs, our bank accounts, our feelings - our selves" (Whutnow, 1993:32). Gibbs (1993:178) kom tot dieselfde konklusie. Hy beweer dat die mens vandag nog steeds soek na sy eie belang en sy eie regte. Hierdie lewenshouding is die gevolg van die modernisme met sy klem op die rasionele en op die lewensruimte van die individu. Ten spyte van die groeiende behoefte aan gemeenskapsbelewing as gevolg van die postmodernistiese paradigma is individualisme dus nog steeds ' $n$ groot struikelblok in die weg van die oplossing van die probleem.

Hendriks en Ludick (1993:814) het ook na 'n ondersoek in Suid-Afrika bevind dat die individualisme die mens so beïnvloed het dat hy nie in diepgaande verhoudinge betrokke wil raak nie. Hierdie konklusie strook met Gibbs (1993:178) se bevinding dat die moderne mens homself nie wil commit nie. Uitgaande van die beskouing dat daar in die huidige kultuur twee paradigmas langs mekaar bestaan, moet die vraag egter gevra word of die mens in staat is om in diepgaande verhoudinge betrokke te raak. Hy het die behoefte aan egte 
gemeenskapsbelewing, maar hy is dus, vanweë sy manipulasie deur die modernisme en sy indiwidualistiese aard, nie in staat om 'n aktiewe en bydraende deel van 'n gemeenskap te wees nie.

Daarom vind gereformeerde kerke dit steeds moeilik, ten spyte van die mens se behoefte aan gemeenskapsbelewing, om bedieningsmodelle daar te stel wat hierdie behoefte kan akkommodeer (vgl. Steenkamp, 1995:604). Die denke oor bediening is, in hierdie kring, nog in so 'n mate gebou op die verbygaande modemistiese paradigna met sy indiwidualisıne dat dit die ontwikkelende postmoderne behoeftes nie kan insluit nie. Hieruit kan afgelei word dat kerklike bediening vasval in die soms teenstrydige behoeftes wat deur die groeiende postmodernistiese en die kwynende modemistiese paradigmas daargestel word. Die opkomende behoefte aan gemeenskapsbelewing kan nie bevredig word nie omdat die modeme mens en die huidige kerklike bediening nog deur die gees van individualisme gedomineer word.

\subsection{Groeiende verstedeliking}

Die afgelope twee eeue is gekenmerk deur die grootste demografiese verskuiwing wat nog in die wêreldgeskiedenis plaasgevind het. Die verskuiwing is die proses van verstedeliking (Caims, 1982:423). In die jaar 1800 was slegs $5 \%$ van die wêreldbevolking in die stede. Hierdie syfer sal in $200055 \%$ beloop (Edgar, 1995:364). Suid-Afrika beleef tans die volle impak van hierdie proses. Die stelselmatige ontvolking van die platteland en die vinnige groei van informele behuising getuig hiervan. Die verstedeliking in Europa en die VSA in die vorige eeu het gepaardgegaan met groot maatskaplike vraagstukke. Hiermee moes die kerklike bediening rekening hou. Hoewel die proses aldaar gestabiliseer het, beleef die Derde Wêreld tans dieselfde problematiek as wat in daardie tyd in daardie wêrelddele aan die orde van die dag was. Die grootste van hierdie probleme is die verskynsel van armoede en dit wat daarmee gepaardgaan verskynsels soos werkloosheid, misdaad, prostitusie, gesinsverbrokkeling en geweld. Hierdie verskynsel stel groterwordende eise aan die kerklike bediening soos wat dit in die negentiende en twintigste eeue in Europa en die VSA die geval was (Stott, 1984:166).

'n Ander belangrike gevolg van verstedeliking is dat die proses 'n eie subkultuur binne 'n gemeenskap daarstel. Benewens al die gevolge van armoede kan op nog vier elemente van so 'n subkultuur gewys word.

\section{- Verstedeliking en mobiliteit binne 'n gemeenskap}

Eerstens lei verstedeliking tot 'n groot mate van mobiliteit binne 'n gemeenskap. Binne in die stede self vind ook baie verşkuiwing plaas. Hierdie verskuiwing lei daartoe dat mense nie die geleentheid het om innige verhoudinge op te bou nie Vir die kerk beteken hierdie verskynsel dat die profiel van 'n stedelike gemeente 
voortdurend verander. 'n Hegte eenheid van mense wat mekaar en mekaar se behoeftes ken, word nie maklik gevorm nie. Die koinonia kom nie tot sy reg nie en dit plaas druk op die bedieningspatrone in hierdie verband. Vanwee die voortdurende verskuiwing word dit moeilik om mense in 'n hegte eenheid van diensbetoon en onderlinge opbou saam te snoer. Hierdie verskynsel lei ook daartoe dat lidmate van kerke dikwels van die kerk vervreem omdat kerklike administrasie nie kan tred hou met die voortdurende verskuiwing nie. Die gesonde toestand van gesinsbediening lei ook skade omdat die stedelike milieu gesinne verplig om op verskillende tye en plekke buitenshuis besig te wees. Vir die kerklike ampsdraer raak dit moeilik om gesinslede op dieselfde tyd by die huis te kry om die bedieningswerk te doen. Die mobiliteit wat deur verstedeliking teweeggebring word, vereis op sigself dus bedieningspatrone wat die subkultuur effektief kan hanteer.

\section{- 'n $\mathrm{Na}$ binne gerigtheid: privatisering}

Tweedens lei verstedeliking tot 'n lewenshouding wat beskryf kan word met die term privatisering. Met diè uitdrukking word bedoel dat die individu, vanwee sy betrokkenheid by sy werk vir die grootste deel van die dag, asook op grond van sy gesins- en familieverpligtinge, 'n besondere behoefte ontwikkel aan privaatheid. Hy onttrek hom dan algaande aan verpligtinge ten opsigte van ander organisasies en instansies. Hierdie tendens word in Suid-Afrika versterk deur die feit dat veral mense in bestuursposisies 'n baie bedrywige beroepslewe het. Die kerk word ook hierdeur ten nouste geraak. Mense is nog bereid om eredienste op Sondae by te woon maar is andersins nie meer betrokke by kerklike aktiwiteite nie. Betrokkenheid by kerklike aktiwiteite gedurende die week gryp in op die privaatheid van die individu en dit is juis hierdie privaatheid wat hy wil beskerm. Hierdie privatisering is die rede waarom al hoe minder mense beskikbaar is vir kerklike diens. Mans wat beskikbaar is om in die ampte van ouderling of diaken te dien word al hoe minder. Privatisering lei ook daartoe dat mense hulleself "na binne rig", met ander woorde, dat hulle nie genee is om hulle eie privaatlewe en sake met ander te deel nie.

\section{- Funksieverskuiwing vanaf die kerk na maatskaplike dienste}

'n Derde belangrike aspek van die subkultuur is die funksieverskuiwing wat plaasvind vanaf die kerk na ander maatskaplike dienste. Vanweě mense se betrokkenheid by hulle werk word al hoe meer dienste, wat vroeèr deur die kerk gelewer is, nou deur die beroepslewe verskaf. Welsynsdienste, huweliksberading en sielkundige hulp word deur werkgewers aan hulle werknemers verskaf en baie gelowiges is eerder by hulle werk betrokke by Bybelstudiegroepe as by die groepe in die gemeente. Pastorale hulp word deur sielkundige dienste vervang en diakonale hulp deur maatskaplike dienste. Na die mens se materiele en geestelike 
belange word op so 'n wyse omgesien dat hy nie meer 'n behoefte het aan kerklike bediening nie

\section{- Tydsbesteding van die stedeling}

Die vierde aspek van die stedelike subkultuur, wat nou saamhang met privatisering, is die tydsbesteding van die stedeling. Hy staan 'n groot deel van sy tyd af aan sy beroep en vanweë die toenemende druk van die beroepslewe is hy gedwing om 'n verdere groot deel af te staan aan rus en ontspanning. Voorts het hy ander gesinsverpligtinge. Betrokkenheid by die kerk lê dus as gevolg hiervan ook al hoe lacr op die agenda Kerklike bediening vind dit toenemend moeilik om binne die raamwerk van die stedeling se tydsbesteding tyd op te eis vir koinonia en kerklike bediening

Hierdie subkultuur, wat as gevolg van verstedeliking ontstaan, is dus 'n struikelblok in die weg van die beoefening van koinonia. Die tendense wat hieruit na vore kom, stel nuwe eise aan kerklike bediening. Die bediening moet binne die milieu van demografiese verskuiwing, privatisering, funksieverskuiwing en die tydsbeperking op 'n effektiewe wyse koinonia daarstel en bevorder. Maatskaplike en sosiologiese veranderinge moet decglik in berekening gebring word, anders gaan die bediening wat met baie sorg beplan en met ywer uitgevoer word, by die mens verby.

\subsection{Verouderde bedieningspatrone}

Met reg kan beweer word dat die basiese patroon van Gcreformeerde bediening oor die afgelope eeu nie veel verander het nie, ten spyte van groot maatskaplike veranderinge wat in die land plaasgevind het. Huisbesoek deur die predikant en die ouderling vind nog grotendeels plaas op die model van dekades gelede. Die bediening in die Gereformeerde Kerke toon steeds duidelik merkbare trekke van die instituutmodel (Vorster, 1995:117). In hierdie model staan die diens van die ampte sentraal ten koste van die diens van die gelowige. Van die uitoefening en belewing van koinonia kom nie veel tereg nie behalwe in die erediens. Dit is so dat verskeie gemeentes sosiale aksies soos gemeentekampe en ander byeenkomste, reël om eenheid en onderlinge sosiale verhoudinge te bevorder maar hierdie aksies bly dikwels kosmeties van aard. Die aksies bevorder vriendskappe en bekendheid met mekaar, maar vestig nie 'n kultuur van blywende koinonia nie omdat voortgaande meelewing en diensgerigtheid ontbreek. Wel het die positiewe praktyk van Bybelstudiegroepe posgevat, maar hierdie groepe betrek gewoonlik slegs ' $n$ klein deel van die gemeente. Met bogenoemde sake inaggenome, het daar in die patroon van bediening nie vecl verander nie, ten spyte van die feit dat groot maatskaplike veranderinge plaasgevind het. Hierdie gebrek aan gefundeerde verandering het meegebring dat bediening in die Gereformeerde Kerke vir die mens al hoe meer irrelevant word soos blyk uit die daling in 
lidmatetal en die afname in kerklike betrokkenheid wat die kerke in die gereformeerde tradisie tans ondervind. 'n Onlangse ondersoek ten opsigte van hierdie tendense onderskryf bogenoemde stelling (GKSA, 1996:1). Gereformeerde bedieningspatrone het nie daarin geslaag om "die tye te verstaan". soos Burger (1995:23) in sy boek oor vernuwing bepleit nie.

Nel (1994:17) dui oortuigend aan dat die gebrek aan stelselmatige vernuwing in die bediening lei tot 'n ongemotiveerde verknogtheid aan die vorme van die verlede en dat die gelowige begin om uitsig te verloor op sy rol en roeping en selfs op God as die Skepper-Versorger-Voleinder. Die kerk word dan vir die mens 'n bastion vir die behoud van die tradisionele patrone en gelowiges word nie meer gemotiveer om volledig Christene te wees in nuwe tye en omstandighede nie.

Om aan die Bybelse eis en die teenswoordige soeke na koinonia effektief gehoor te gee sal die Gereformeerde bediening op grond van Bybelse bedieningsbeginsels ook in hierdie opsig vernuwe moet word. Daarmee word nie 'n radikale breuk met die verlede of die invoer van allerlei kunsmatige oppervlakkige aksies bepleit nie. Waama gesoek word, is bedieningspatrone wat Bybels-prinsipieel verantwoord is, die positiewe en werkbare van die verlede behou en wat op gefundeerde en effektiewe wyse die problematiek van die veranderende samelewing en in besonder die soeke na gemeenskap hanteer Hierop word verder ingegaan.

\section{Bedieningsmodelle vir die bevordering van gemeenskaps- belewing}

Verandering van bedieningsmodelle sal nutteloos wees as dit gebaseer word op 'n kerkbeskouing wat nog rus in die ou paradigma, met ander woorde, in die oordrewe klem op die instituutmodel met sy verabsolutering van die besondere dienste. Hierdie model kan nie reg laat geskied aan die volle belewing van die gemeenskap tussen gelowiges nie. Wat nodig is, is 'n herwaardering van die volle omvang van kerk-wees, soos dit uitgedruk word in die baie beelde wat die Bybel gebruik om die kerk te beskryf. 'n Vernuwing van kerkbegrip is nodig sodat al die aspekte wat die Bybelse beelde van die kerk impliseer, in die hedendaagse bediening na vore kan kom.

Die opbou en groei van die lewende gemeenskap met God in die kerk impliseer terselfdertyd die openheid vir lewende gemeenskap met ander gelowiges. In die oorbring van die heil wat in Christus verwerf word, word die kerk deur die Heilige Gees tot ' $n$ heilsgemeenskap gemaak. Hierdie belangrike aspek van die kerk moet in die denke van die moderne gelowige indring. Hy moet wegkom van die idee dat die kerk buite homself slegs bestaan in ampsdraers of die uitsprake van kerklike vergaderings 
Hierdie verandering in denke oor die kerk moet veral toespits op die verhouding tussen die rol van die besondere dienste en die rol wat die gelowige in die diens van die gelowige moet speel. Louw (1990:220) stel met 'n treffende beeld twee vorme van kerk-wees teencor mekaar. In die een vorm is die kerk soos 'n gondel waar daar een roeier is terwyl die ander mense in die boot passiewe passasiers is. Hierdie gondel stel die instituutmodel van die kerk voor waar die aktiwiteit van die gemeente opgaan in die kerkraad terwyl die gelowiges passiewe en onbetrokke toehoorders is. Daarteenoor vergelyk hy die kerk met 'n roeiboot waar almal besig is om te roei. Dié beeld stel die kerk voor waar kerkraad en gemeente almal aktief betrokkc is in die roepingsvervulling van die kerk. Voordat die gemeenskapsbelewing in die kerk tot sy reg kan kom, moet die idee van die kerk as 'n roeiboot eers posvat. Hierdie siening van die kerk moet deur die amptelike bediening, erediensbelewing en die ander fasette van kerk-wees wakker gemaak word. Met dié standpunt as voorvereiste kan nou gelet word op aspekte van bediening wat kan bydra tot vernuwing in gemeenskapsbelewing.

\subsection{Prediking en kategese}

Die prediking en die kategese is die belangrikste elemente in die bediening waardeur die leer en lewe van gelowiges opgebou word Hierdie elemente moet aangewend word om die hedendaagse gelowige bewus te maak van die belangrike roeping van gemeenskapsbelewing wat hy in sy diens as gelowige moet vervul. Die prediking moet aandui dat die gelowige se verhouding met God ook 'n innige verhouding met sy naaste impliseer. Hy moet opgeroep word tot diens en ondersteuning vall sy naaste en tot bereidheid om deur sy medegelowiges geestelik opgebou te word. Prediking wat slegs aandag gee aan die persoonlike verhouding tot God en die ewe belangrike gcmeenskap van die gelowiges afskeep, is piêtisties en verkondig 'n halwe evangelie. Die prediking moet die gees van individualisme bestry omdat dit in stryd is met die Bybelse idee van koimonia.

Voorts moet in die prediking ook aandag gegee word aan die negaticwe gevolge van 'n institusionalistiese kerkbegrip met sy instituutmodel. Gelowiges moet verstaan dat hulle die kerk is en dat die kerk leef en aktief is wanneer die ledemate van die liggaan, naamlik die gelowiges, binne hulle onderlinge verbondenheid aan mekaar leef en aktief is. Institusionalisme lei tot formalistiese verhoudinge en sulke verhoudinge verstar die lewe en beweging binne die gemeente. Hierop wys Hattingh (1988:140) in sy navorsing oor die persoonlike gemeenskap met (ind as die korrektief op formalisme in die godsdiens. Die prediking, moet weer aan gelowiges 'n egte kerkbesef gee soos wat dit was tydens die Reformasie (Berkhof \& De Jong, 1967:177). 'n Skrifverantwoorde kerkhegrip, volgens die Bybelse beelde van die kerk, motiveer gelowiges om hulle 
roeping in hulle diens as gelowiges te vervul want dan verstaan elkeen dat hy, vanweë sy eie gawes, 'n unieke plek en rol binne die gemeente vervul.

Die kategese kan in hierdie verband ook 'n belangrike rol speel. Jongmense moet hulle doop verstaan as inlywing in die gemeente en dat hulle daardeur volledig deel het aan die verbondsverhouding. Hierdie verhouding is ' $n$ verhouding met God en met mekaar. Ook hulle het gawes en verpligtinge wat in die gemeente ontplooi moet word. Te min van hierdie besef kom in Gereformeerde gemeentes tereg en dit lei daartoe dat jongmense en kinders hulleself as onvolledige lidmate ervaar. Hulle beleef die kerk as 'n grootmenswêreld wat net die behoeftes van volwassenes hanteer (GKSA, 1996:7). Die diens wat die jongmens ten opsigte van die belewing van koinonia kan lewer, moet deur die kategese ontgin en ontwikkel word. Dieselfde kan in hierdie verband ook gesê word oor die belangrikheid van die ontwikkeling van 'n Skrifverantwoorde kerkbegrip.

\section{2 'n Lewende erediens}

Die gemeenskap van die gelowiges word sigbaar uitgedruk in die erediens want in die erediens kom gelowiges immers byeen om God gesamentlik te aanbid. Hierop is in 'n vorige artikel reeds uitvoerig gewys en daarom word slegs enkele gedagtes kursories beklemtoon. Besondere klem moet gelê word op die "gesamentlikheid" van die erediens en aspekte waarin hierdie saak na vore kom, moet in die teenswoordige bediening uitgebou en benadruk word. Die indruk wat bestaan dat die Gereformeerde erediens 'n monologiese karakter het waarin die liturg aktief, en die res passief is, moet uit die weg geruim word omdat die indruk indruis teen die wese van die erediens. Dié beskouing, wat by baie Gereformeerdes leef, is ook 'n res van die rasionalisme (Strydom, 1994:98). Die erediens moet worship wees in die ware sin van die woord. Hierdie gesamentlikheid kan, soos reeds gesê is, uitgedruk word in sang, belydenis, gebed, verootmoediging en barmhartigheidsdiens.

Die gemeenskap van die gelowiges word veral treffend weerspieel in die viering van die Nagmaal. Daar is die Here en sy volk bymekaar as ' $n$ vooruitwysing na die bruilofsmaal van die Lam. In die Gereformeerde bediening moet veel meer gemaak word van die viering van die Nagmaal sodat die gemeenskapskarakter pertinent na vore kom sonder om die ander aspekte van die sakrament af te skaal. Dit kan gedoen word deur meermale Nagmaal te vier soos die gebruik was in die voeg-Christelike kerk (Walker, 1992:23). Gelowiges moet ook geleer word om die simboliek van die Nagmaal te begryp om sodoende die gemeenskapskarakter sterker te beleef.

Wat egter belangrik is, is dat die eenheid en spiritualiteit wat deur die erediens as gesamentlike aanbidding geskep word, moet uitkring na al die ander fasette van kerkwees. Koinonia moet nie by die erediens ophou nie. Die gees van die 
erediens moet invloei in die lewe. Die lewende erediens moet dien as die kragstasie wat die vitaliteit van geloofsverhoudinge in die samelewing daadwerklik uitbou. Erediens en lewe moet geïntegreer word sodat die postmodeme mens die laste van individualisme en privatisering kan afskud. Die kwaliteit van gemeenskapsbelewing in die daaglikse lewe word wesentlik bepaal deur die kwaliteit van gemeenskapsbelewing in die erediens. Vernuwing van die erediens sal ook positief bydra tot vernuwing van gemeenskapsbelewing

\subsection{Huisbesoek}

Die huisbesoek deur die predikant en die ouderling kan beskou word as een van die sterk punte van die Gereformeerde bediening. Hierdie praktyk bevorder die toepassing van die tug wat een van die merktekens van die ware kerk is (Nederlandse Geloofsbelydenis art 29). In die praktyk skep huisbesoek ook 'n noue vertrouensverhouding tussen die dienskneg en die gelowige en waar die huisbesoek reg gedoen word, word die gelowige geestelik opgebou. Met huisbesoek wat rég gedoen word, word bedoel 'n besoek aan die gelowige waar die betrokke predikant of ouderling die gelowige deur vermaning en bemoediging opbou in die geloof en lewensheiliging. Huisbesoek moet nie versand in 'n gesellige "sosiale kuiertjie" nie. Soos in die amptelike bediening van die Woord moet die gelowige gekonfronteer word met die Bybelse eise van 'n gehoorsame lewe Hierdie opbouende praktyk moet in die Gereformeerde bediening gehandhaaf word. Tog moet daarby gesê word dat huisbesoek, omdat dit indiwidueel gerig is, nie die onderlinge verhoudinge tussen gelowiges versterk nie Die gelowige het kontak met sy predikant en sy ouderling maar hierdie kontak op sigself bning hom nie in kontak met medegelowiges nie. Die huisbesoek moet dus aangevul word met ander aksies waardeur gelowiges met mekaar in kontak gebring word. Hierdie kontak moet meer wees as slegs sosiale kontak op gesellige byeenkomste. Belangrike navorsing word in hierdie verband gedoen oor die rol wat kleingroepbediening ten opsigte van dié leemte kan speel. In hiedie verband kan veral gewys word op die invloedryke werk wat Neighbour (1990) en Gibbs (1992 en 1993) in hierdie verband gedoen het. Die gebruik van kleingroepe word reeds op so 'n wye vlak in Protestantse kerke toegepas dat Beckham (1995:260) beweer dat dit die uitstaande kenmerk van kerke in die eenen-twintigste eeu gaan wees. Op die gebruik van kleingroepe vir die bevordering van gemeenskapsbelewing binne die Gereformeerde kerke word vervolgens gewys.

\subsection{Kleingroepbediening}

Om die belewing van gemeenskap en die onderlinge opbou van gelowiges te stimuleer, word in die huidige navorsing oor bediening baie aandag gegee aan die rol wat kleingroepe in die gemeente kan speel (Mitchell, 1995:157). Hierdie kleingroepe binne die gemeente kan die vorm aanneem van Bybelstudiegroepe, 
gebedsgroepe, ondersteuningsgroepe, gespreksgrocpe, evangeliseringsgroepe en groepe wat allerlei dienste in die gemeente kan lewer. Die groepe kan ook verskillende vorme aanneem, soos die tradisionele wykstelsel in die Gereformeerde bediening, of in belangegroepe na gelang van die omstandighede in die gemeente.

Beckham (1995:29) het 'n besondere studie gemaak van die dinamiek wat kleingroepe kan meebring. Hy sê dat die waarde van die kleingroep daarin geleě is dat dit nie net op Sondae vergader nie, maar ook gedurende die week. Hierdie groepe word basiese geloofgemeenskapseenhede in die gemeente. In die groepe word gelowiges toegerus vir diens aan mekaar en gelowiges word vir mekaar verantwoordelik. So figureer 'n basiese model wat in die Nuwe-Testamentiese kerk teenwoordig was, en die "vir mekaar"-opdragte van die Bybel kan effektief uitgevoer word. Die gawes van die Gees aan gelowiges kan doeltreffend funksioneer. In die groepe is die rol van die predikant daarin geleë om volgens Efesiërs 4:12 toe te rus en oorhoofse leiding te gee, sonder om die groepe te oorheers en sodoende te domineer. Die kleingroep stimuleer gemeenskapsbelewing op 'n organiese wyse binne die gemeente.

Gerigte navorsing oor dié saak binne die raamwerk van Gereformeerde bediening word tans deur Oostenbrink (1996) gedoen. In sy vroeere navorsing het hy bevind dat kleingroepe van waarde kan wees in die uitvoering van die evangeliseringsroeping in die stad (Oostenbrink, 1994:85). Met sy huidige navorsing wat gegrond is op grondige bevindings van onlangse navorsing in hierdie verband toon hy aan hoe kleingroepe die belewing van gemeenskap in die gemeente versterk en bydra tot gefundeerde en verdiepte spiritualiteit van diegene wat daarby betrokke is

Met kleingroepbediening kan die struikelblokke wat die subkulture van die verstedelikingsproses veroorsaak, ook oorkom word. Vanweě die informele aard en stimulering van deelname is dit makliker om mense in kleingroepe te organiseer as in 'n groot formele groep soos in 'n hele gemeente. In 'n kleingroep raak die indiwidu en sy nood ook nie so maklik weg nie en kan die tendense van indiwidualisme en privatisering van die lewe effektief ondervang word.

Die vestiging van kleingroepe as bedieningswyse in 'n Gereformeerde gemeente is kerkregtelik moontlik en hoef, onder sekere voorwaardes, nie afbreuk te doen aan vasstaande bedieningsbeginsels nie. Kleingroepbediening soos Oostenbrink (1996) dit prinsipieel en prakties uitspel, kan 'n belangrike en werkbare weg wees vir Gereformeerde bediening in die nuwe postmoderne paradigma wat die kerk besig is om binne te gaan. Kerke kan in die beplanning van bediening in die gemeentes hieraan nougesette aandag gee. 


\subsection{Dienslewering in die samelewing}

In die instituutmodel van die kerk is die gelowige hoofsaaklik passief, behalwe in sy betrokkenheid by die sogenaamde amptelike kerklike aktiwiteite. Soos reeds gesê is, word in die kerklike lewe van hierdie model van die kerk af wegbeweeg as gevolg van 'n nuwe postmodemistiese paradigma. Mead (1993:43) sê dat in die nuwe paradigma die rol wat die gelowige kan speel, weer ontdek word. Hy voorspel dat die diens van die gelowige homself in die toekoms gaan manifesteer in diens wat gelowiges, selfs oor kerkgrense heen, in die samelewing gaan lewer. In Gereformeerde taal beteken dit dat die diens van die gelowige weer beklemtoon word. Hierdie ontwikkeling moet verwelkom word en gesien word as die logiese konsekwensie van die refonmatoriese kerkbeskouing. Bediening behoort daarom ook daarop gerig te wees om gelowiges in die erediens, huisbesoek en kleingroepe toe te rus en te organiseer om sulke diens op al die terreine van die samelewing te lewer. Om van diens te wees aktiveer die mens en versterk die onderlinge verhoudinge. So word die koinonia gedien.

\section{Slot}

Mead (1993:84) sê: "A new church is being born around us." Hierdie "nuwe kerk" is 'n model waarin gemeenskapsbelewing sterk figureer. Hierdie model het nog sterk wortels in die verlede en die mooie en bruikbare van die wortels behoort nie ontken en uitgerangeer te word nie. Terselfdertyd moet die kerklike bediening egter rekening hou met die nuwe werklikheid waarin die kerk inbew'eeg. Hierdie werklikheid stel nuwe eise, maar bied ook ruim geleenthede. Die postmoderne mens soek vandag na die belewing van geestelike gemeenskap met sy naaste, al word sy lewe nog bepaal deur die reste van 'n modernistiese era wat verbygaan. Die kerk, en juis die kerk as uitdrukking van ware koinonia kan hierdie vraag beantwoord. Bedieningspatrone moet voortdurend ondersoek en aangepas word om op grond van die Bybelse beginsels vir bediening die postmoderne mens se soeke na gemeenskap effektief te akkommodeer.

\section{Bibliografie}

ALAND, K 1986. A history of Christianity Philadelphia : Fortress Press. Volume 2

BECKHAM, W A. 1995 The second reformation Reshaping the church for the twenty-first century Houston : Touch Publications

BERKHOF, H \& DE JONG, O J 1967. Geschiedenis der kerk. Nijkerk Callenbach

BREYTENBACH, H.S 1992 . Metafore vir die kerk en riglyne vir gemeentebou Nederduits Gereformeerde Teologiese Tydskrif, 33(3):391-407, September

BRUEGGEMAN, W 1991 Rethinking models through Scripture Theology Today, (2):128138, Jul

BROMILEY, GW 1978 Historical theology An introduction Grand Rapids William B Ferdmans 
BURGER, C 1995. Gemeentes in transito Vernuwingsgeleenthede in 'n oorgangstyd. Kaapstad : Lux Verbi

CAIRNS, E.E 1982. Christianity through the centuries. Grand Rapids : Zondervan Publishing House

CAMPBELL, R.A. 1989. Essential aspects of the church in the Bible. Evangelical Review of Theology, 13(1):5-22, Jan.

DE HAAN, P. 1996. Why folks leave the church. The Banner, 131(3) 12-15, Jan

DULLES, A. 1987. Models of the church. New York : Double Day.

EDGAR, W. 1995. No news is good news: Modernity, the post-modern and apologetics. The Westminster Theological Journal, 57(2):359-382.

EDWARDS, D.L. 1987. The futures of Christianity. London : Hodder and Stoughton

GEREFORMEERDE KERKE IN SUID-AFRIKA 1996. Rapport van die deputate insake dalende lidmaatgetalle. Potchefstroom : Admin Buro

GIBBS, E. 1992. I believe in church growth London : Hodder and Stoughton

GIBBS, E 1993. Winning them back Tackling the problem of nominal Christianity Kent Monarch Publications

HAUCK, F, 1968. Koinos (In Kittel, G Theological dictionary of the New Testament. Grand Rapids Wiliam B. Eerdmans Volume 3:789-809.)

HATTINGH, C. 1988. Persoonlike gemeenskap met God as kortektief op formalisme in die godsdiens - 'n pastorale studie. Potchefstroom : PU vir CHO. (Th $\mathrm{M}$-verhandeling)

HENDRIKS, J. 1992 Gemeentes vertel Verandering in 'n Christelike geloofsgemeenskap Kaapstad : Lux Verbi

HENDRIKS, H.J. \& LUDICK, C.B. 1993. Koinonia in die stad: Verhoudinge in die groter stadsgemeentes van die gereformeerde kerke Hervormde Teologiese Siudies, 49(4): 810-822, Nov.

KUHN, T.S. 1970. The structure of scientific revolutions Chicago The University of Chicago Press

KÜNG, H. 1991. Theology for the third milienium An ecumenical view Glasgow Harper Collins.

KÜNG, H. 1995. Christianity. The religious situation of our time London : SCM Press

LOUW, D.J. 1990. Charisma en amp. Op soek na 'n koinoniale diensmodel vir gemeentebou Nederduits Gereformeerde Teologiese Tydskrif, 31(2):220-239, Jun.

MARCUSE, H. 1971. De eendimensionele mens; studies over de ideologie van de hoogindustriele samenleving Bussem: Paul Brand

McRAY, J.R. 1984. Fellowship. (In Elwell, W A ed Evangelical dictionary of theology. Grand Rapids : Baker Book House. p. 414)

MEAD, L.B. 1993. The once and the future church. Reinventing the congregation for a new mission frontier. New York: The Alban Institute

MITCHELL, G 1995 Small groups (In Buchanan, D \& Hendriks, J. eds Meeting the future - Christian leadership in South Africa Randburg : Knowledge Resources p 157-163.) 
NEIGHBOUR, R.W. 1980. Where do we go from here? A guidebook for the cell group church. Houston : Touch Publications.

NEL, M. 1994. Gemeentebou Halfway House : Orion Press.

NEUENZEIT, P. 1961. Koinonia. (In Buchberger, M ed. Lexicon für Theologie und Kirche Freiburg : Verlag Herder. Deel 6:368-369.)

OOSTENBRINK, J.W. 1994. Kleingroepevangelisering in die stad Potchefstroom : PU vir CHO. (Th. M.-verhandeling.)

OOSTENBRINK, J.W. 1996. Korporatiewe spiritualiteit en kleingroepleierskap Potchefstroom : PU vir CHO. (Ph.D -proefskrif)

PANNENBERG, W. 1989. Christianity in a secularised world London SCM Press.

SCHILDER, K 1953 Christus en cultuur. Franeker : Wever.

SEESEMANN, L.H. 1933 Der begriff Koinonia im Neuen Testament. Giessen : Verlag von Alfred Töpelmann

STEENKAMP, L.J.S. 1995. Die kerk onderweg na die een-en-twintigste eu: 'n Kritiese besinning oor kerkwees in 'n veranderende konteks in Suid-Afrika Henormde Teologiese Studies, 51(3):604-622, Sept.

STOTT, J.R.W. 1984. Issues facing the church today. Hants : Marshalls

STOTT J.R.W. 1992 The contemporary Christian An urgent plea for double listening Leicester : Inter-Varsity Press

STRYDOM W.M. 1994 "Sing nuwe sange, nuutgebore" Liturgie en lied. Bloemfontein : UOVS

VON ARX, H. 1989. Koinonia auf Altkirchlicher Basis Bern : Internationalen Kirchlichen Zeitschrift

VORSTER, J.M. 1994 Kerkvernuwing in die lig van Bybelse begrippe vir die kerk. In die Skriflig, 28(4):509-525, Des

VORSTER, J M. 1995. Die bydrae en relevansie van die ekklessiologiese besinning in die GKSA In die Skriflig, 29(1 en 2):117-134, Maart en Junie

WALKER, W 1992. A history of the Christian church. Edinburgh : T \& T Clark.

WUTHNOW, R 1993 Christianity in the twenty-first century. Reflections on the challenges ahead. Oxford : Oxford University Press 
